\title{
Peptostreptococcus elsdenii from the Caecum of Pigs
}

\author{
By D. GIESECKE, SOLVEIG WIESMAYR AND M. LEDINEK* \\ Institut für Tierphysiologie, Universität München, München, Germany \\ (Accepted for publication I October 1970)
}

Large, Gram-negative, anaerobic cocci (LC) fermenting lactate were first isolated by enrichment culture from the sheep rumen (Elsden, Volcani, Gilchrist \& Lewis, 1956). High counts (about $10^{9} / \mathrm{ml}$.) were obtained from young calves but not from adult ruminants by Hobson, Mann \& Oxford (1958). The cocci were cultured in numbers of $10^{6}$ to $10^{3} / \mathrm{ml}$. from the rumen of cattle fed high-grain rations and named Peptostreptococcus elsdenii by Gutierrez, Davis, Lindahl \& Warwick (I959). They can be important fermenters of lactate in the rumen and are associated with amylolytic lactate producers such as Streptococcus bovis when large amounts of starch are consumed by ruminants. The production of propionic acid by $P$. elsdenii via the acrylate pathway (Ladd, 1959) has attracted the particular interest of biochemists and nutritionists. The types of bacteria active in the rumen are not found only in this organ (Giesecke, 1970), and recent experiments indicate that $P$. elsdenii is also a prominent lactate fermenter in the large intestine of pigs fed on diets containing potatoes.

\section{METHODS}

Media. Reinforced clostridial agar (RCM, Oxoid Ltd) in roll-tube cultures with a gas phase of $5 \%(\mathrm{v} / \mathrm{v}) \mathrm{CO}_{2}+95 \%(\mathrm{v} / \mathrm{v}) \mathrm{N}_{2}$ was used for initial isolation, and a semisolid lactate medium similar to that of Hobson et al. (1958), but incubated under pure $\mathrm{N}_{2}$, was used for subculturing, preserving and testing isolates.

Isolation. Samples of caecum contents were obtained from six pigs with caecum cannulae, three of which were fed on raw potatoes and three on steamed potatoes (Ledinek, I970). Amounts of $10 \mathrm{~g}$. were vigorously shaken with $90 \mathrm{ml}$. of anaerobic mineral buffer solution (Bryant \& Burkey, 1953), and diluted through $10^{-11}$ before inoculation into RCM.

Biochemical reactions and $p H$. Biochemical tests were performed according to Hobson et al. (1958) with I \% (w/v) of substrates replacing lactate in the semisolid medium. For growth at different $\mathrm{pH}$ values the lactate medium was buffered with tris-maleate (Geigy, 1968). All pH values were measured with a glass electrode, and fermentation acids determined by gas chromatography (Ledinek, 1970).

\section{RESULTS}

After 2 to 3 days of incubation in RCM tubes the large Gram-negative cocci formed greenish yellow, circular colonies $\mathrm{I}$ to $2 \mathrm{~mm}$. in diameter, in numbers corresponding to viable counts of $10^{9}$ to $10^{10} / \mathrm{g}$. caecum contents. The properties of 13 isolates are listed in Table I. Viable bacteria observed after incubation (for $24 \mathrm{~h}$.) in semisolid medium

* Present address: Ziuinorejsko Veterinarski Zavod Ptuj, Yugoslavia. 


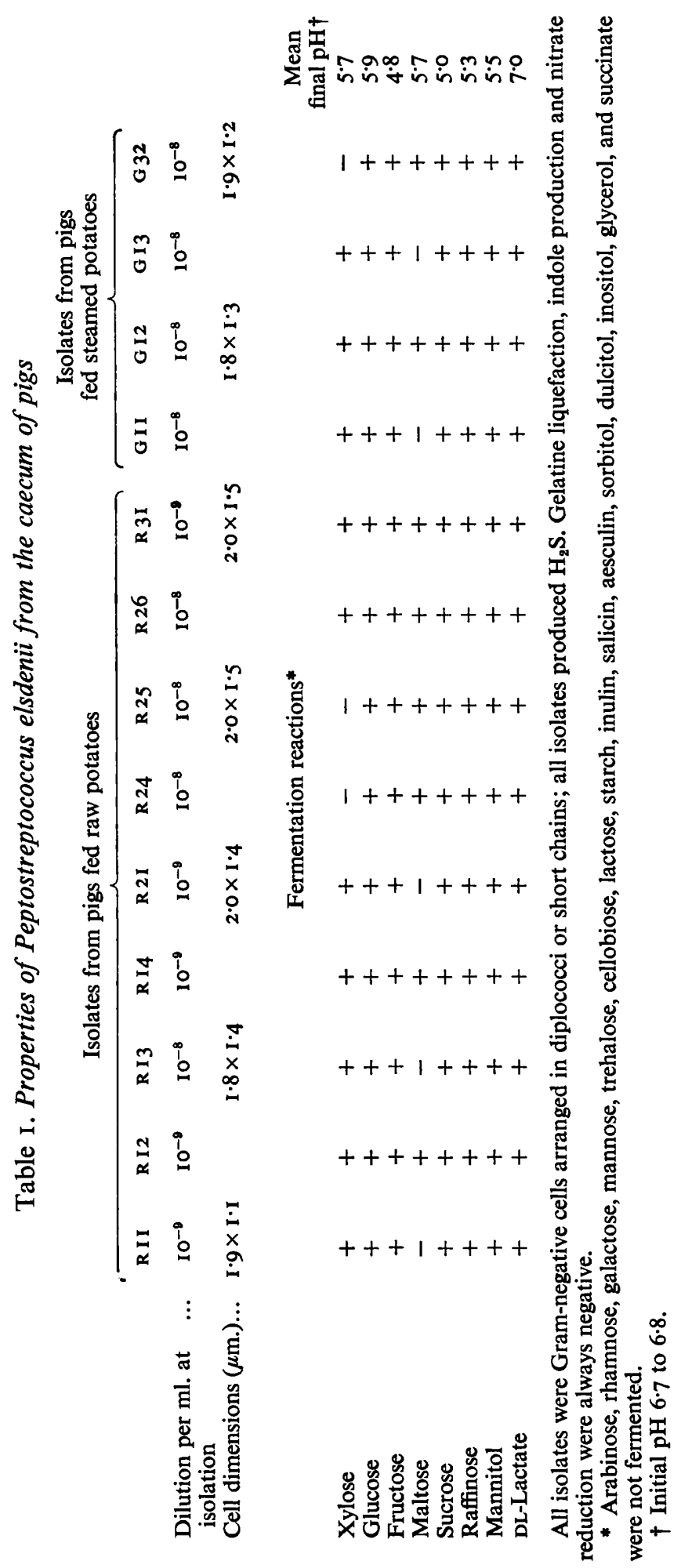


showed pronounced flattening of adjacent cell walls and occurred in pairs and short chains of up to ro cells. In older cultures bacteria of variable size were observed, sometimes arranged in long chains of more than 50 units.

In addition to lactate a limited number of substrates were fermented with the production of gas, which was not analysed. Preliminary observations on five isolates indicated that acetic, propionic, butyric and valeric acids were the fermentation acids from lactate, and caproic acid was formed in addition from glucose. Of seven strains tested at different $\mathrm{pH}$ values, all grew at $\mathrm{pH} 5 \cdot 2$ to $7 \cdot 2$, three at $\mathrm{pH} 7 \cdot 8$, but none at $\mathrm{pH} 5.0$ or below or $\mathrm{pH} 8 . \mathrm{I}$ or above. Sodium citrate, which was first tried as a buffer, inhibited growth even at concentrations of $0.0 \mathrm{I} \mathrm{M}$. Of five isolates tested, all grew at $37^{\circ}$ and $42^{\circ}$, two at $45^{\circ}$, and three at $30^{\circ}$, but no growth was observed at $25^{\circ}$ or $50^{\circ}$.

On the basis of these characters it is concluded that the strains of large Gramnegative cocci from the caecum of pigs belong to the species Peptostreptococcus elsdenii.

\section{DISCUSSION}

Dimensions, Gram-negative staining, anaerobiosis, utilization of lactate, production of $\mathrm{H}_{2} \mathrm{~S}$ and of fatty acids with 2 to 6 carbon atoms are distinctive features of Peptostreptococcus elsdenii (Elsden et al. 1956; Gutierrez et al. 1959). The isolates from pigs are similar to rumen strains, though some differences appear to exist. The size is smaller than that given for isolates from the rumen $(2.4 \times 2.6 \mu \mathrm{m}$.), but the ages of the latter cultures were not reported. The pig strains differed from those of Elsden $e t$ al. (1956) and Hobson et al. (1958) in fermenting sucrose and raffinose but not sorbitol, and in variable fermentation of maltose and xylose. The strains of Gutierrez et al. (1959) failed to attack sorbitol and mannitol but some fermented sucrose and glycerol. Peptostreptococcus elsdenii from calves produced growth at a broader range of $\mathrm{pH}$ $(4 \cdot 8$ to $8 \cdot \mathrm{I})$ than pig strains and seemed less sensitive to citrate (Hobson et al. 1958$)$.

Gram-negative, anaerobic cocci resembling Peptostreptococcus elsdenii were cultured only occasionally and in very low counts from the gut of young pigs by Fuller \& Lev (1964). In the present experiments the pigs were reared, housed, and cared for separately and had thus no contact with ruminants. Microscopic observations showed that Gram-negative cocci accounted for about $25 \%$ of the total bacteria in their caecum contents, and large Gram-negative cocci were $17.4 \%$ of the total anaerobic bacteria $\left(\mathrm{IO}^{10}\right.$ to $\mathrm{IO}^{11} / \mathrm{g}$. caecum contents) cultured on RCM by Ledinek (1970). On feeding potatoes, considerable amounts of carbohydrate escape pancreatic digestion and are fermented in the large intestine where lactic acid appears to be an important intermediate. It is thus obvious that $P$. elsdenii may occupy an ecological niche in digestive tract habitats other than the rumen.

\section{REFERENCES}

Bryant, M. P. \& Burkey, L. A. (1953). Cultural methods and some characteristics of some of the more numerous groups of bacteria in the bovine rumen. Journal of Dairy Science 36, 205-21 7.

Elsden, S. R., Volcani, B. E., Gilchrist, F. M. C. \& Lewis, D. (1956). Properties of a fatty acid forming organism isolated from the rumen of sheep. Journal of Bacteriology 72, 68I-689.

Fuller, R. \& LEV, M. (1964). Quantitative studies on some of the Gram-negative anaerobic bacteria in the pig alimentary tract. Journal of Applied Bacteriology 27, 434-438.

GeIGy, A. G. (1968). Documenta Geigy, Wissenschaftliche Tabellen. 7. Auflage, Basel.

GIESECKE, D. (1970). Comparative microbiology of the alimentary tract. In Physiology of Digestion and Metabolism in the Ruminant. Edited by A. T. Phillipson. Newcastle upon Tyne: Oriel Press. 
GutierRez, J., Davis, R. E., Lindahl, I. L. \& Warwick, E. J. (I959). Bacterial changes in the rumen during the onset of feedlot bloat of cattle and characteristics of Peptostreptococcus elsdenii n. sp. Applied Microbiology 7, I6-22.

Hobson, P. N., ManN, S. O. \& Oxford, A. E. (1958). Some studies on the occurrence and properties of a large Gram-negative coccus from the rumen. Journal of General Microbiology r9, 462-472.

LADD, J. N. (1959). The fermentation of lactic acid by a Gram-negative coccus. Biochemical Journal 7I, I6-22.

LEDINEK, M. (1970). Untersuchungen über die Beteiligung von Mikroorganismen am Verdauungsstoffwechsel des Schweines bei Fütterung von rohen und gedämpften Kartoffeln. Dissertation (VeterinärMedizin), Universität München, Germany. 